\title{
Are Turkey's Restrictions on Freedom of Religion or Belief Permissible?
}

\author{
Mine Yıldırım \\ Norwegian Helsinki Committee \\ yildirim@nhc.no
}

\begin{abstract}
This article constitutes a summary of the findings of an inquiry into the utilization of the restriction clause of freedom of religion or belief in the course of restriction of this right in Turkey. It demonstrates that FoRB is restricted in various ways by public authorities which rarely involve a systematic application of the FoRB restriction clause. Despite Turkey's human rights obligations in the area of freedom of religion or belief and the high status conferred to international human rights law under Article 9o of the Turkish Constitution the impact of international provisions on the protection of FoRB in Turkey remains insufficient and inconsistent. The right to freedom of religion or belief has been restricted through measures based on "established practice", decisions of public authorities based on laws and regulations not directly dealing with this right and court decisions that are not in full compliance with international law.
\end{abstract}

\section{Keywords}

Turkey - freedom of religion or belief - limitations

\section{Introduction}

Since the early 2000 individuals and religious/belief communities have increasingly brought their cases to domestic and international human rights compliance control mechanisms with respect to Turkey's most deeply rooted freedom of religion or belief (FoRB) issues. This trend may be indicative of a desire to achieve change through law. However, whether change may be achieved through law remains a question since even domestic court decisions 
and judgments at the European Court of Human Rights (ECtHR) level have not resulted in resolving the disputed issues. The application of the limitation clause of the right to FoRB by domestic courts has varied significantly in Turkey.

This article presents the findings of an inquiry into the utilization of the limitation clause of FoRB in the course of restriction of this right. It demonstrates that FoRB is restricted in various ways by public authorities which rarely involve a systematic application of the FoRB limitation clauses. This may be explained by the hierarchisation theory, where FoRB disputes are decided on the basis of the dominant doctrines of religion and national interests. ${ }^{1}$ In what follows a brief review of religious demographics and a critical overview of the general Turkish legal framework for the protection of FoRB are presented. This introduction is followed by an examination of the types of FoRB restrictions, namely, restrictions based on established practice, provisions or laws that are not explicitly FoRB related, and partial references to international standards on FoRB. Finally, a competent application of the limitation clause wherein the exercised right finds legitimacy through a changed political will, such as in the case of the headscarf, is presented by way of contrast.

\section{The Context}

\subsection{Turkey's Religious Demographics}

Turkey's population is religiously diverse and religion and ethnicity are often conflated. ${ }^{2}$ This diversity stands in contrast to the generally presented homogenous picture of Turkey as a country with a $99 \%$ Muslim population. ${ }^{3}$ Official statistics on religious demographics are not kept. According to the International Religious Freedom Report of 2017 released by the U.S. Department of State, $77 \%$ is Hanefi Sunni, $25-31 \%$ is Alevi, $4 \%$ is Shia Jaferi. ${ }^{4}$ Non-Muslim religious groups constitute less than $1 \%$ of the population. ${ }^{5}$

1 P.G. Danchin, 'Of Prophets and Proselytes : Freedom of Religion and the Conflict of Rights in International Law', 49(2) Harvard International Law Journal (2008).

2 Turkey's population is 80.8 million according to Turkish Statistics Institute (2017 figures).

3 It has not been possible to confirm this information with the General Directorate of Civil Registration and Nationality.

4 US Department of State, International Religious Freedom Report on Turkey (2017).

5 Ibid. Approximately 90,000 Armenian Apostolic Orthodox Christians; 25,000 Roman Catholics; 25,000 Syrian Orthodox Christians; 16,000 Jews; 15,000 Russian Orthodox Christians; and 10,00o Bahai's. Others include: 1,00o Ezidis; 5,00o Jehovah's Witnesses; 7,000 Protestant denominations; 3,ooo Chaldean Christians; and 2,0oo Greek Orthodox Christians. 


\subsection{1} International Human Rights Obligations

Turkey has committed to significant international human rights obligations as a party to core universal and regional human rights treaties. ${ }^{6}$ However, it has deposited important interpretive declarations, thus reserving the right to interpret and apply the provisions on the protection of minorities in accordance with the Turkish Constitution and the Treaty of Lausanne. Another sensitive area concerns education. Turkey has ratified Protocol I of the European Convention on Human Rights; however, an interpretive declaration has been formulated with respect to Article 2, the right to education. Under the latter, states have an obligation to 'respect the rights of parents to ensure such education and teaching in conformity with their own religious and philosophical convictions'. Turkey's interpretive declaration states that this provision will be interpreted in line with Law No. 6366 on the unification of education. ${ }^{7}$ Evidently, Turkey's reservations or interpretive declarations point to two areas of rights that seem to have domestic sensitivity; namely religious education and protection of minority rights. ${ }^{8}$

Turkey's international human rights commitments take precedence over domestic law, including constitutional provisions. Article 90 of the Turkish Constitution recognizes the supremacy of duly ratified international treaties on human rights over domestic legislation. ${ }^{9}$ The application of this provision by domestic courts has been, however, limited and subject to wide discretion granted to the judiciary without much guidance as to the application of this norm. ${ }^{10}$

6 Convention Against Torture, International Covenant on Civil and Political Rights, Convention on the Elimination of all forms of Discrimination Against Women, International Convention on the Elimination of All Forms of Racial Discrimination, International Covenant on Economic, Social and Cultural Rights, Convention on the Rights of All Migrant Workers and Members of the Their Families, Convention on the Rights of the Child.

7 Ratified 18 May 1954, see Turkey's declaration, available at http://conventions.coe.int/Treaty /Commun/ListeDeclarations.asp?NT=009\&CM=7\&DF=18/04/2012\&CL=ENG\&VL=1.

8 For more on Turkey's human rights obligation in the area of FoRB, see M. Ylldırım, The Collective Dimension of Freedom of Religion-A Case Study on Turkey (Abingdon: Routledge, 2017).

9 Article 9o of the 1982 Turkish Constitution. This amendment was adopted in 2004. See Kemal Başlar, 'Uluslararası Antlaşmaların Onaylanması, Üstünlüğü ve Anayasal Denetimi Üzerine' [On the Ratification and Superiority of International Treaties], 24:1-2 Milletlerarası Hukukve Milletlerarası Özel Hukuk Bülteni (2004).

10 İbrahim Şahbaz, 'Avrupa İnsan Hakları Sözleşmesi'nin Türk Yargı Sistemindeki Yeri' [The Place of the European Convention on Human Rights in the Turkish Judicial System], 54 Türkiye Barolar Birliği Dergisi, Eylül/Ekim (2004), p. 216. 
Generally, Turkey not only has failed to apply Article 9 of the ECHR effectively nationally, numerous ECtHR judgments that have found a violation on the part of Turkey of Article 9 or Article 2 of Protocol 1 have also not been enforced. ${ }^{11}$ The weak enforcement is illustrative of Turkey's reluctance to take required measures when these are linked to domestically sensitive issues. The ECtHR has decided on some key issues related to FoRB, namely, the compulsory Religious Culture and Ethics lessons, in Hasan and Eylem Zengin v. Turkey and Mansur Yalçın and Others v. Turkey, ${ }_{1}^{12}$ coercion to disclose religious affiliation in national identity cards, in Sinan Işıkv. Turkey, ${ }^{13}$ conscientious objection to military service, in Ercep v.Turkey, Feti Demirtas v. Turkey, Mehmet Tarhan v. Turkey, Halil Savda v. Turkey and Osman Murat Ülke v. Turkey, ${ }^{14}$ the status of place of worship, in Cumhuriyetçi Kültür ve Eğitim Vakfı v. Turkey ${ }^{15}$ and Association of Jehovah's Witnesses v. Turkey, ${ }^{16}$ and public funding of religious services, in Izzettin Doğan and Others v. Turkey. ${ }^{17}$

The Lausanne Peace Treaty, in addition to being the founding document of the modern Turkish state, establishes the minority protection regime for Turkey's non-Muslim communities. Articles 37-45 of the Lausanne Treaty cover the protection of non-Muslim minorities; ${ }^{18}$ Turkey, however, continues to restrict or prevent non-Muslim minorities from fully enjoying their rights

11 See Norwegian Helsinki Committee Freedom of Belief Inititive, Monitoring Report on the Right to Freedom of Religion or Belief in Turkey 2015 (Istanbul, 2016).

12 Respectively, Hasan and Eylem Zengin v. Turkey, 9 October 2007, European Court of Human Rights, No. 1448/o4; and Mansur Yalçın and Others v. Turkey, 16 September 2014, European Court of Human Rights, No. 21163/11.

13 Sinan Isik v. Turkey, o2 February 2010, European Court of Human Rights, No. 21924/05.

14 Ercep v. Turkey, 22 February 2012, European Court of Human Rights, No. 526o/o7; Feti Demirtas v. Turkey, 17 January 2012, European Court of Human Rights, No. 5260/o7; Mehmet Tarhan v. Turkey, 12 July 2012, European Court of Human Rights, No. 9078/o6; Halil Savda v. Turkey, 12 June 2012, European Court of Human Rights, No. 2458/12; Osman Murat Ülke v. Turkey, 24 April 2006, European Court of Human Rights, No. 43965/o4.

15 Cumhuriyetçi Eğitim ve Kültür Merkezi Vakfi v. Turkey, European Court of Human Rights, No. 32093/10, 19 February 2019.

16 Association of Jehovah's Witnesses and Others v. Turkey, 24 May 2016, European Court of Human Rights, Nos. 36915/10 and 8606/13.

17 Izzettin Doğan and Others v. Turkey, 26 April 2016, European Court of Human Rights (Grand Chamber), No. 62649/10.

18 Article 40 protects the rights to establish, manage and run charity institutions, religious social institutions, schools, educational institutions and language rights. Article 41 protects the right to education in one's mother tongue in primary schools. Article 42 sets forth the facilitation of the establishment of religious institutions. 
by restrictive interpretations, adoption of incompatible laws, bureaucratic obstacles and arbitrary decisions of public authorities. ${ }^{19}$

In conclusion, Turkey has significant international human rights obligations in the areas of FoRB and related rights and these are yet to be implemented systematically by courts and administrative authorities, as will be further shown below.

\subsubsection{Turkish Constitution and the Protection of Freedom of Religion or Belief}

The 1982 Turkish Constitution embodies key elements that reflect Turkey's approach toward religion and FoRB. Paradoxically, while the principle of secularism, defined as separation of state and religion, is given a central place, state involvement in religion is permanently established through, inter alia, the Presidency of Religious Affairs and compulsory religion lessons in schools and the interpretation of secularism in a way to justify state interference in religious affairs and as well as through the facilitation of Islamic religious services.

Under Turkey's 1982 Constitution, secularism is given a paramount place; it is one of the attributes of the Republic and irrevocable. ${ }^{20}$ Reform laws, are directly or indirectly linked to secularism and 'no provision of the Constitution shall be construed or interpreted as rendering [them] unconstitutional. ${ }^{21}$ The principle of non-interference in the affairs of religious communities is not envisioned in the Turkish legal framework. This has significant implications for FoRB, particularly in its collective dimension.

The Turkish Constitutional Court (Anayasa Mahkemesi, hereafter, CC) has traditionally understood the principle of secularism to mean, firstly, that religion cannot in any way interfere in state affairs and secondly, since the CC views secularism as the "heart" of the system it adopts an "active approach" toward its protection. ${ }^{22}$ More recently, since 2012, however, the CC has issued an evolved jurisprudence which has been framed as "liberal secularism" (özgürlükçü laiklik in Turkish); accordingly, 'individual preferences and the ensuing lifestyles remain outside the interference of the state, instead, they are under

19 For examples, see D. Kurban and K. Hatemi, Bir Yabancılaştırma Hikayesi: Türkiye'de Gayrimüslim Cemaatlerin Vakıf ve Taşınmaz Mülkiyeti Sorunu (Istanbul: TESEv, 20o9).

$20 \quad 1982$ Constitution of the Republic of Turkey, Articles 2 and 4 .

21 Ibid., Article 174.

22 B. Dinçkol, 1982 Anayasası Çerçevesinde ve Anayasa Mahkemesi Kararlarında Laiklik [Secularism Within the Framework of the 1982 Constitution and the Judgments of the Constitutional Court] (Kazancı Kitap, 1992), p. 64. 
the protection the state..$^{23}$ This evolved position was first outlined in a case dealing with the introduction of optional religion lessons in Islam through legislative change. ${ }^{24}$ The CC held that one of the purposes of the secular state is to establish a political order where, while protecting social diversity, individuals of different beliefs can live together in peace. Accordingly, the state will refrain from interfering in the right to FoRB unless it is necessary and in order to remove obstacles to the exercise of this right. Despite this ostensibly positive theory of secularism, while applying the principles to the facts of the case, considering the constitutionality of the legislation introducing the elective religion courses, the CC effectively attributes to the state a positive obligation to provide Islamic religious services; notably in school education, since the Turkish state holds a monopoly over religious education and does not allow private citizens to establish institutions that teach religion. ${ }^{25}$

Another contradiction to the principle of secularism is found in the Presidency of Religious Affairs (the Diyanet) - a public institution 'within the general state administration' with the mandate to exercise its duties 'as prescribed under its particular law' and 'in accordance with the principles of secularism' aiming at 'national solidarity and unity'. ${ }^{26}$ The purpose of the Diyanet is stipulated in its own law, 'Carrying out activities related to the beliefs, worship and ethics of the Islamic religion, enlightening the society about religion and administrating worship places.. ${ }^{27}$

The right to freedom of religion or belief is enshrined in Article 24 of the Constitution provides:

(1) Everyone has the right to freedom of conscience, religious belief and conviction. Acts of worship, religious services, and ceremonies shall be conducted freely, provided that they do not violate the provisions of Article 14.

(2) No one shall be compelled to worship, or to participate in religious ceremonies and rites, to reveal religious beliefs and convictions, or be blamed or accused because of his religious beliefs and convictions.

23 Turkish Constitutional Court, 25 May 2012, E/2012/48 and K/2012/75. The judgment reviewed the constitutionality of Primary School and Education Law No. 6287 adopted on 3o March 2012.

24 Ibid.

25 Ibid.

26 Constitution of the Republic of Turkey, Article 136.

27 Law No. 633, Official Gazette No. 12038, 2 July 1965. For a critical overview of the Presidency of Religious Affairs, see İ. Gözaydın, Diyanet: Türkiye'de Dinin Tanzimi [The Diyanet: Arrangement of Religion in Turkey] (Istanbul: İletişim, 2009). 
(3) Education and instruction in religion and ethics shall be conducted under state supervision and control. Instruction in religious culture and moral education shall be compulsory in the curricula of primary and secondary schools. Other religious education and instruction shall be subject to the individual's own desire, and in the case of minors, to the request of their legal representatives.

(4) No one shall be allowed to exploit or abuse religion or religious feelings, or things held sacred by religion, in any manner whatsoever, for the purpose of personal or political influence, or for even partially basing the fundamental, social, economic, political, and legal order of the state on religious tenets.

The first paragraph constitutes the inviolable part of the right to freedom of religion or belief, namely the right to freedom of conscience, religion, belief and convictions. This right includes the right not to believe and change one's religion or belief. This provision, however, is not interpreted as broadly as to include the protection against being compelled to act against one's conscience. The second paragraph sets out the scope of the protection afforded to manifestations - even though this term is absent in the provision - which is limited to "worship, religious services and ceremonies" in contrast to the protection afforded to the non-exhaustive list of manifestations of religion or belief in "worship, observance, and teaching" stipulated in Article 9 of the ECHR. The gap between these differing formulations is not explicitly protected. However, more recently, the CC's jurisprudence has evolved to extend the scope of protection, in theory, to the scope of Article 9 of the ECHR, including the right to manifest one's religion or belief in worship, teaching, practice and observance. ${ }^{28}$

Teaching religion or belief, as a form of manifestation of religion, is not expressed as a right, instead, it is referred to in the context of strict state control in Article 24(3) through the regulation concerning compulsory Religious Culture and Knowledge of Ethics classes and other religious instruction which can only be carried out under state supervision. Through this provision the state takes upon itself the role of teaching religion.

There are several constitutional provisions that function as limitation clauses for the right to freedom of thought, conscience and religion. The limitation enshrined in Article 24(5) stating that 'no one shall be allowed to exploit or abuse religion or religious feelings or things held sacred by religion' is a special constitutional limitation that is intrinsic to the provision. "Abuse of religious feelings", "things held sacred by religion", all are vague terms that may be 
difficult to reconcile with clarity and foreseeability criteria that are required for permissible limitations. The general limitations clause that is applicable to all fundamental rights is found under Article 13. It stipulates that fundamental rights may be restricted 'only by law', without 'infringing upon their essence', and limitations may not be 'in conflict with the letter and spirit of the Constitution and the requirements of the democratic order of society and the secular Republic and the principle of proportionality'. ${ }^{29}$ The requirement of the "secular Republic" and the special protection of Reform Laws have often been utilized to restrict fundamental freedoms in the past. ${ }^{30}$

Consequently, the right to FoRB is subject to a number of limitation clauses with varying degrees of precision and pertinence. It will not be difficult to predict, then, that the interpretation and balancing of high courts play an important role in the determination of permissibility of limitations.

\section{3}

\section{Forms of Restrictions of Freedom of Religion or Belief}

\subsection{Restrictions Based on "Established Practice"}

The right to freedom of religion or belief is often restricted through arbitrary political decisions implemented in administrative processes. This is particularly evident in relation to the so-called "Lausanne minorities" and administrative restrictions have been utilized over the years in the context of, among others, property used for religious purposes or education. The election and appointment of the religious leaders illustrate this type of restriction particularly well.

The Lausanne Treaty protects FoRB and the right of non-Muslims to run their religious institutions freely; however, it does not specify a certain procedure for the election of religious leaders. ${ }^{31}$ The process of selecting leaders for the Armenian, Jewish and Greek communities takes place in the state apparatus' executive section lacking precise, accessible and foreseeable rules. According to the Ministry of Interior's Directorate of Minority Issues Evaluation Section, for example, in the appointment of the Armenian Patriarchate, a certain legal framework exists, namely, 'Articles 37-45 of the Lausanne Treaty and the ancient precedents and customs of the community'. ${ }^{32}$ Since the meaning of "ancient precedents and customs" is vague and is inevitably linked to the question

29 Constitution of the Republic of Turkey, Article 13.

$30 \quad$ Ylldırım, supra note 8.

31 Articles 38-44.

32 E-mail response to information request from Ministry of Interior, 27 August 2010. 
of who determines what these are minorities in question are forced to remain dependent on the public authorities to determine applicable rules.

Since the establishment of the Turkish Republic, the Jewish, Greek Orthodox and Armenian Apostolic communities have sought state permission when electing their religious leaders although such permission is not set out explicitly in law, it is de facto required by established practice. The elections of the Chief Rabbi and the two Patriarchs follow a procedure that is defined throughout the process and 'each election is different'. ${ }^{3}$ The religious leader must be a Turkish citizen, have certain religious training, and must 'have a good reputation in the eyes of the state and society' ${ }^{34}$

The obstruction in the election of a Patriarch for the Armenian Apostolic community in the last ten years has been the most striking example of the impact of the state interference at hand. Following the health-related seclusion of the Patriarch elected for life, the question of a successor became an important one for the community's religious affairs. ${ }^{35}$ When the community wanted to elect a new or co-Patriarch, the government has assumed the role of an arbiter and informed the Armenian community and imposed a solution, namely that they can elect a Patriarch Vicar. ${ }^{36}$ Most recently the Armenian community attempted to elect a new Patriarch in the spring of 2018 and once again faced interference from the Ministry of Interior by way of the Istanbul Governorship informing them that they cannot elect a new patriarch. ${ }^{37}$

These interferences have not been the subject of a court decision since they had not been challenged by the members of these communities at court. It is clear, however, that the administrative authorities have not made references to or followed provisions on FoRB, including the limitation clause since the written communications do not make any reference to FoRB.

\subsection{Restricting FoRB through "Other Laws" with Varied Reference to FoRB Provisions}

The protection of the right to establish places of worship in Turkey serves as a good illustration of the nature of de jure and de facto restrictions. There

33 Interview with the representative of the Armenian community who wished to remain anonymous (2018).

34 Ibid.

35 M. Ylldirım and O. Oering, TURKEY: Why state interference in the election of Chief Rabbi, Greek Orthodox and Armenian Patriarchs?, F18News (2010), www.forum18.org/archive .php?article_id=1477.

36 Ibid.

37 For a detailed analysis, see Mine Ylldırım, Why Can't Armenians Elect a New Patriarch, Forum 18, www.forumi8.org/archive.php?article_id=2352\&pdf=Y, 15 February 2018. 
are 88,681 mosques in Turkey, ${ }^{38}$ yet they may only be administered by the Presidency of Religious Affairs, which means that a group of Muslims may not establish their own mosque if they wished to remain outside the Presidency of Religious Affairs structure. The Alevi, ${ }^{39}$ may establish cultural associations where they assemble for worship, yet these are denied the official status of a place of worship based on the Presidency of Religious Affairs' view that 'Muslims worship in mosques' ${ }^{40}$ Relatively newer religious groups, like Protestants and Jehovah's Witnesses, have been generally tolerated by public authorities when they worship in premises they consider places of worship. However, successful acquisition of place of worship status has been rare (as further discussed below).

Despite the important legislative change in the Public Works Law whereby the word "mosque" was replaced by the phrase "place of worship", ${ }^{41}$ less than a handful of applications for place-of-worship status for venues other than mosques have been successful. ${ }^{42}$ While the phrase "place of worship" in the legislation implies a neutral and broad scope of protection, in practice, this term has been interpreted narrowly to encompass exclusively mosques and mesjid, churches and synagogues.

Not having a place-of-worship status, believers who assemble in their worship places run the risk of interference by public authorities. More fundamentally, however, the persistent denial of granting of place-of-worship status undermines justice and continues to nurture the deeply entrenched inequalities.

Reference to relevant provisions of international human rights law by public authorities and domestic courts when assessing claims related to places of worship varies considerably. The acquisition of place-of-worship status requires the 'approval of the highest civilian administrator'.43 Since criteria for the assessment of applications for approval is not explicitly stipulated,

382018 statistics from the Presidency of Religious Affairs, stratejigelistirme.diyanet.gov.tr/say fa/57/istatistikler, accessed 30 July 2019 .

39 The Alevi are a Muslim minority which combines Shi'ism with a combination of sufism. See T. Olsson, E. Ozdalga, C. Raudvere (eds.), Alevi Identity: Cultural, Religious and Social Perspectives (London and New York: Routledge, 1998).

40 Opinion of the Diyanet, Communication No. 1773, sent by the Diyanet to the Interior Ministry on 17 December 2004.

41 Imar Kanunu [Public Works Law], Law No. 3194, 3 May 1985; R.G. No. 18749, 9 May 1985, Additional Provision 2 (amending Article 9), 15 July 2003. Article 9 of Imar Kanunu [Public Works Law], 2003.

42 Şar Aşmayim Sinagog in Kemerburgaz, Istanbul (2006) and the Istanbul Protestant Church (2006) in Altıntepe.

43 Imar Kanunu [Public Works Law], supra note 41. 
religious or belief groups applying to the relevant public authorities do not have access to clear and foreseeable criteria.

Court cases concerning the approval of places of worship are scarce in number. Since most applications of Protestants to the municipalities for the designation of places of worship have not been accommodated, these applications have not come to the stage of being considered by the "highest civilian public authority". ${ }^{44}$ It has been reported that two applications, by the Diyarbakır Protestant Church and the Van Protestant Church, are pending with the respective public authorities. ${ }^{45}$ The Association of Jehovah's Witnesses has not been able to obtain place-of-worship status for any of the Kingdom Halls despite having made applications. This denial has been the subject of an application to the ECtHR which has found a violation of Article 9 in 2016; the repeated refusals interfered with the applicants' right to FoRB, finding that the measures were not proportionate to the aim pursued and not necessary in a democratic society. ${ }^{46}$ Particularly important is that the ECtHR observed that there is no indication that domestic courts have tried to balance different interests and assess the proportionality of the different measures. ${ }^{47}$ To date, none of the Kingdom Halls of Jehovah's Witnesses has place-of-worship status and therefore face the risk of closure.

There are court cases concerning places of worship and the approval of public authorities related to Alevi worship places, cem houses, where the relevant Governorships have denied approval. In this context two reasons stand out; the Diyanet opinion and the Law No. 677 concerning the closure of tekke and zaviye-although reference to this opinion as a ground appears to have been abandoned. Firstly, a Communication sent by the Diyanet to the Interior Ministry reads: 'It is not possible to consider cemevi and other places as places of worship because Alevism, which is a sub-group within Islam, cannot have a place of worship other than mosques or mesjid that are common places of worship within Islam. 48

44 In practice there have been two successful applications for designation of places of worship.

45 E-mail correspondence with the representative of the Association of Protestant Churches on 23 July 2013, on file with the author.

46 Association of Jehovah's Witnesses and Others v. Turkey, 24 May 2016, European Court of Human Rights, No. 36915/10 and 8606/13.

47 Ibid., para. 104.

48 Communication No. 1773, sent by the Diyanet to the Interior Ministry on 17 December 2004. For example, concerning an application for the opening a cem house at the Türkiye Büyük Millet Meclisi (Turkish Grand National Assembly, твмм) where there is currently only a mesjid found, the Presidency of the твмм rejected it with reference to the Diyanet 
The second objection - still relevant - centers on the Law on the Obstruction of Dervish Lodges (Tekke) and Shrines (Turbe) and the Prohibition of Abolition of the Position of Caretakers of Shrines and Certain Titles (hereafter Law No. 677) which has been the basis for the nationwide closure of the tekke, ${ }^{49}$ in $1925 .{ }^{50}$ The Law No. 677 has a special legal status; as a reform law which aims to protect secularism it cannot be understood to be contrary to the Constitution. ${ }^{51}$ Article 1 of Law No. 677 declares the closure of all tekke and zaviye and türbe which have been traditional places of worship or centers of religious activity for various Islamic traditions, including the Alevi tradition. ${ }^{52}$ The law is not a neutral law in the sense of closing places of worship generally; instead it names the types of places of worship it abolishes. ${ }^{53}$

Law No. 677 has been critical in relation to the non-recognition of cem houses as places of worship. In a case related to the construction of a cem house, the Çankaya Cemevi Yaptırma Derneği (Çankaya Cem House Building Association, ÇCYD) has been prosecuted for describing the cem house as a place of worship in the association statutes. Following the refusal by the ÇCYD of the request from the Interior Ministry to remove the references to cem house as a place of worship from its statute, ${ }^{54}$ the Governorship initiated a court case to close the association. ${ }^{55}$ The first-degree court relied on Article 9 of the ECHR and held that the right to FoRB includes the right to establish places of worship. ${ }^{56}$ It held that the rituals in the cem houses may indeed be prohibited by Law No. 677, but these needed to be assessed in light of contemporary legal norms. The court, without applying ECtHR reasoning systematically, held that taking into account Article 9 of the ECHR and the principle of secularism in the Constitution the state cannot determine what constitutes "worship or a place of worship"

Opinion on cem houses. Milliyet, 'Meclis'te Cemevi Talebine Ret' [Refusal to Cemevi Request at the Assembly], 9 July 2012.

Tekke are places where sufi thought, understanding and discipline are studied and presented to the people. M. Kara, Din Hayat Sanat Açısından Tekkeler ve Zaviyeler [Dervish Lodges from the Perspective of Religion, Life, Art] (Istanbul: Dergah Publications, 1999), p. 43 .

50 Tekke ve Zaviyeler ile Türbelerin Seddine ve Türbedarlar ile Bazı Unvanların Men ve İlgasına Dair Kanun [Law on the Closure of the Dervish Lodges and Shrines], Law No. 677, 30 November 1925 .

51 Article 174 of the Turkish Constitution.

$5^{2} \quad$ Kara, supra note 49 .

53 In the following decades many shrines and dervish lodges were opened as museums.

54 The Directorate for Associations of the Ministry of Interior sent a letter to the Ankara Governorship, referring to this Diyanet opinion of 30 March 2005, Letter No. 1277.

55 Ankara 16th Peace Court, 4 October 2011, E. 2010/492.

$56 \quad$ Ibid. 
and found that the establishment of cem houses are not contrary to the ECHR, or the Turkish Civil Code, ${ }^{57}$ nor the Law on Associations. ${ }^{58}$ In conclusion, there was no need to dissolve the association.

The Court of Appeals, however, overturned the decision of the first instance court and held that Law No. 677 closes tekke and zaviye; however, it allows mosques and mesjid..$^{59}$ Law No. 677 does not refer to cem houses. The Court of Appeals also recalled the status of Law No. 677 and said that none of its provisions may be interpreted as being incompatible with the Constitution. ${ }^{60}$ It argued that Law No. 677 excludes the establishment of any Islamic place of worship other than mosques or mesjid. ${ }^{61}$

Interestingly, the reasoning did not consider whether the cem house is equivalent to tekke or zaviye, instead, it proceeds with the assumption that Law No. 677 only allows mosques and mesjids. Therefore, based on the reference to an "unlawful" place of worship in the association's statute, the Court of Appeals concluded that the statute of the association is contrary to the law which necessitates the dissolution of the association. ${ }^{62}$

The reasoning of the Court of Appeals does not include any reference to the right to FoRB, nor does it consider the consequences (proportionality) of the denial of the recognition of the cem houses as places of worship for the association or the Alevi community. Despite the judgment of the Court of Appeals, the first-degree court insisted on its judgment. The case was considered by the Joint Civil Divisions of the Court of Appeals which, as described in detail below relied on Article 9o and upheld the judgment of the first-degree court.

Another relevant case concerns the compulsory Religious Culture and Ethics course which has been subject of two ECtHR judgments. ${ }^{63}$ The cases concern complaints of Alevi parents on the basis of the right to education protected under Article 2 of Protocol No. 1. The ECtHR held that this course does not meet the required criteria of objectivity and pluralism and that the Turkish

57 Turk Medeni Kanunu [Turkish Civil Code], No. 4721, 22 November 2001.

$5^{8}$ Dernekler Kanunu [Law on Associations], No. 5231, 17 July 2004.

59 Radikal, 'Yargitay Cemevine Kapıyı Kapattı' [The Court of Appeals Closed the Door on Cem Houses], 25 July 2012.

6o Ibid.

61 7th Chamber of the Civil Division of the Court of Appeals, 10 May 2012, E2012/262, $\mathrm{K} 2012 / 3351$.

62 Article 89 of the Civil Code stipulates that when the purpose of an association becomes contrary to law and morals a court will decide for its dissolution. Medeni Kanun [Civil Code], Law No. 4721, 22 November 2001, Official Gazette No. 24627, 8 December 2001.

63 Hasan and Eylem Zengin v. Turkey, 9 October 2007, European Court of Human Rights, No. $1448 / 04$. 
educational system fails to respect parents' right to raise their children in accordance with their religious or philosophical views.

While the judgments have initiated a process of revising the content of the curricula and books of the compulsory Religious Culture and Ethics course in Turkey, the course content is yet to become compatible with human rights standards. ${ }^{64}$ Moreover, despite ECtHR judgments domestic courts have given conflicting judgments, some finding a violation of Article 24 for the refusal of exemption applications made by parents with reference to the ECtHR jurisprudence and judgments, while others finding a non-violation for the same demands by parents. The determining factor in different judgments has been the difference of opinion on the nature of the course, namely, whether it constitutes instruction in religion or a neutral course about religions. ${ }^{65}$

Consequently, either through administrative decisions, as in the case of places of worship, or in relation to applications for exemption from the compulsory Religious Culture and Ethics courses, FoRB provisions including the limitations clause have either not been applied at all or they have been applied inconsistently.

\subsection{Application of Article 9o}

As explained above, Article 9o of the Turkish Constitution establishes the supremacy of international human rights provisions over domestic law; where national provisions contradict provisions in human rights treaties Turkey has ratified, courts are to directly apply the latter. The application of Article 90 has not been extensive including in cases related to FoRB by lower and higher courts; however, there are exceptions.

The ECtHR has delivered judgments on Turkey regarding conscientious objection. ${ }^{66}$ The right to conscientious objection to military service is not recognized in Turkey; however, two military court decisions constitute exceptions to the practice of other domestic courts. One concerned a Jehovah's Witness conscientious objector, Barış Görmez, the other a Muslim conscientious objector,

\footnotetext{
64 See NHC/IOG, Submission to the Committee of Ministers of the Council of Europe on the Execution of Judgment on Zengin Group of Cases (2019).

65 AIHMIZ, Report the Execution of Hasan and Eylem Zengin/TurkeyJudgment (2013).

66 For a list of the judgments and the state of enforcement, see Norwegian Helsinki Committee Freedom of Belief Initiative, Monitoring Report on the Right to Freedom of Religion or Belief in Turkey (2015), accessible at: http://inancozgurlugugirisimi.org /en/monitoring-report-on-the-right-to-freedom-of-religion-or-belief-in-turkey-2015-is -published/.
} 
Muhammed Serdar Delice. ${ }^{67}$ In both cases military courts, to some degree, relied on the jurisprudence of the ECtHR on conscientious objection following the Bayatyan v. Armenia case.

Yet these court judgments should be read carefully, as they show the limits of the right to conscientious objection as it has been recognised by the military courts and other courts have not adopted this position. The courts' application of ECtHR jurisprudence in these cases of conscientious objectors lacks coherence. Two requirements stand out: first, the courts require that the religion held by the conscientious objector is known to reject military service; and secondly, that the conscientious objector's "sole and undivided" motivation for rejecting military service is his conscientious objection declared at the start of compulsory military service. ${ }^{68}$

Malatya Military Court's Delice decision outlines the Turkish military judiciary's interpretation of the right to conscientious objection to military service. The applicant had declared his conscientious objection, based on his Islamic and nationalist beliefs, approximately five months after he had been conscripted. The Military Court interpreted the ECtHR's approach to the right to conscientious objection as one based on the theological position of a religious group, and excluded the beliefs of the individual. In the case of the Jehovah's Witnesses the Military Court said, 'persons who are members of the Jehovah's Witnesses reject military service, because they are part of this group or institution which fundamentally rejects military service. ${ }^{69}$ In the Malatya Military Court's view, Delice belonged to 'Islam which is not a belief or ideological movement that rejects the performance of military service. ${ }^{70}$ The Court also argued that Delice did not, from the beginning of his military service, have a "sole and undivided purpose" of conscientious objection.

Relying on Article 9o of the Constitution and the jurisprudence of the ECtHR the Isparta Military Court recognised the right to conscientious objection to military service and acquitted Jehovah's Witness Baris Görmez in $2012 .{ }^{71}$ This judgement did not involve any detailed assessment of the limitation clause of Article 9 of the ECHR or Article 24 of the Constitution, rather a reference to the recognition of the right to conscientious objection to military service. These judgments remain isolated judgements. They have not led to a changed jurisprudence on other issues or to legislative change.

67 M. Ylldırım, TURKEY: Selective progress on conscientious objection, Forum 18, www.forum 18.org/archive.php?article_id=1696, 1 May 2012.

68 Ibid.

69 Ibid.

$70 \quad$ Ibid.

71 Ibid. 
Another important utilization of Article 9o, this time by the Joint Civil Divisions of the Court of Appeals, related to the status of Alevi cemevi as places of worship in the case considered above-the case of the association (Çankaya Cemevi Yaptırma Derneği) that aimed to build an Alevi place of worship. Despite domestic legal provisions, including in Law No. 677 and the Law on Associations that may provide grounds for the closure of the association, the Court relied essentially on Article 11 of the ECHR which protects the right to associate including with a religious purpose. It was granted that the limitation on the right to association was prescribed by law; however, the limitation did not pursue a legitimate aim and was not necessary in a democratic society. On the contrary, dissolving the foundation may result in the disruption of public order and peace. Subsequently, the Joint Divisions upheld the decision of the first-degree court and underlined that if individuals are given the right to believe-stressing that Alevis are not prohibited from believing in the Alevi faith - then they should also be allowed to establish places of worship and associations to build these places of worship. ${ }^{72}$

Numerous first degree and regional Court of Cassation decisions dealt with the Ministry of Education's rejection of requests for exemption from the compulsory Religious Culture and Ethics (RCE) course. In recent years while not all, a significant number of decisions relied on the jurisprudence of the ECtHR, particularly its findings concerning the Turkish RCE course. In these cases the issue has not been the incompatibility of domestic law and international human rights standards since under the Turkish Constitution the RCE course ought to be "teaching about religions" and not religious instruction. The issue has been whether the nature of the RCE as taught in schools amounts to such objective teaching about religions. The ECtHR found that, despite changes, 'the Turkish education system offers no appropriate options for the children of parents who have a religious or philosophical conviction other than that of Sunni Islam' and that the violation of Article 2 of Protocol No. 1 stems 'from a structural problem, ${ }^{73}$

It is important to note that the above mentioned national judgments have been related to individual cases and have not led to changes in legislation or general administrative practice. Legal remedies need to be pursued in each individual case and go through lengthy processes. The decisions of the Constitutional Court, however, have a greater potential to create far-reaching

72 Joint Civil Divisions of the Court of Appeals, 3 December 2014, E. 2014/7-1038 K. 2014/99o.

73 Mansur Yalçın and Others v. Turkey, 16 September 2014, European Court of Human Rights, No. 21163/11, paras. 77 and 84 . 
change. As it will be shown below, controversial FoRB cases have yet to be considered by the Constitutional Court.

\subsection{FoRB Cases under the Turkish Constitutional Court Individual Complaint Mechanism}

The constitutional amendment adopted by the public referendum on 12 September 2010 authorized the Turkish Constitutional Court to conclude and finalize individual applications. ${ }^{74}$ "Individual application" is a specific remedy available for those who claim their rights under the Constitution. The purpose of the individual application mechanism is to prevent violation of fundamental rights guaranteed under the Constitution and to redress existing violations. When the Constitutional Court establishes that a fundamental right was violated by a public act, it considers whether or not retrial is required to redress this violation or it may rule for compensation. The decision of the Constitutional Court specifies what should be done to redress a violation and its consequences when required.

There are few decisions dealing with FoRB but many individual applications on diverse FoRB issues are on the list to be considered, including one on the right to conscientious objection that has been referred to the Plenary Assembly in February 2016, due to the substantive issues it covers. ${ }^{75}$ To date the Constitutional Court delivered inadmissibility judgments dealing with property issues of religious communities; ${ }^{76}$ and furthermore in relation to complaints about the high volume of the call to prayer on grounds of the complaints being ill-founded; ${ }^{77}$ and claims to use of Hagia Sofia Museum as a mosque due to inadmissibility rationae persone..$^{78}$

The Constitutional Court's most confident judgments on FoRB have been on the issue of the headscarf. The case of Tuğba Aslan, ${ }^{79}$ a Plenary Assembly judgment, has laid down the new position of the Constitutional Court on the headscarf. The case dealt with the application of a female lawyer who wanted to participate in a hearing wearing her headscarf. The applicant complained that the judge's decision for non-continuation of the hearing because of her

\footnotetext{
74 The Court started to receive applications as of 23 September 2012.

75 Bianet, 'Vicdani Ret AYM Genel Kurulu'nda', 23 February 2016.

76 Kilikya Ermeni Katalikosluğu K.T., Mardin Katolik Kilisesi, 15 June 2016, Constitutional Court.

77 D.Ö., 30 June 2016, Constitutional Court, Application No. 2014/3977; R.G. Tarih ve Sayl, 13 October 2016, No. 29856.

78 Sürekli Vakıflar Tarihi Eserler ve Çevreye Hizmet Derneği, Constitutional Court, 13 September 2018, Application No. 2015/14747.

79 Tuğba Arslan, Constitutional Court, 25 June 2014, Application No. 2014/256.
} 
headscarf violated a number of rights including her right to freedom of religion and conscience. The elaborate reasoning refers to the key aspects of the ECtHR's case-law on FoRB and General Comment No. 22 of the UN Human Rights Committee. A violation of Article 24 of the Constitution was found already based on the question of whether the interference was prescribed by law, where the CC found that it was not because the Court of Cassation had already suspended the rule on the clothing requirements for lawyers which included the rule stating that female lawyers could not cover their head. In this case the judge had created law and this did not comply with the principle of legality. ${ }^{80}$

In addition a violation was found of Article 10, the principle of equality. Since the first-degree court had relied on singling out the 'headscarf as a strong religious and political symbol that is opposed to secularism' the CC found that this differential treatment needed to be justified. ${ }^{81}$ The CC observed that the first-degree court did not demonstrate that the manifestation of religion in question harmed rights and freedoms of others or public order, but considered the headscarf as opposed to secularism in theory.

The assessment by the CC of the interference with the right to freedom of religion or belief on grounds of the principle of secularism is very relevant and interesting considering that, in the past, this principle has been widely used to restrict the practice of religion or belief. For such a limitation to be legitimate one has to establish that the behaviour, attitude or acts of the person in question are violating the principle of secularism. ${ }^{82}$ One would have to demonstrate that the use of the headscarf has an aggressive, oppressive, provocative purpose or the purpose to interfere in others' beliefs and impose one's own beliefs on others or that it corrodes societal order, creates disorder. ${ }^{83}$ Any limitation of any right in the Constitution cannot be based on abstract concerns or assumptions, but must be based on facts and irrefutable reasons. ${ }^{84}$

The case of Esra Nur Özbey provided the CC with an opportunity to further elaborate its position on the headscarf as well as the relationship between secularism and the use of headscarves by civil servants. ${ }^{85}$ The applicant complained that her dismissal from public service violated her right to freedom of religion or belief. The CC followed the standardized tests set out by the EctHR so as to establish whether there was an interference in the right to FoRB, whether it was prescribed by law (deciding that it was not necessary to make a

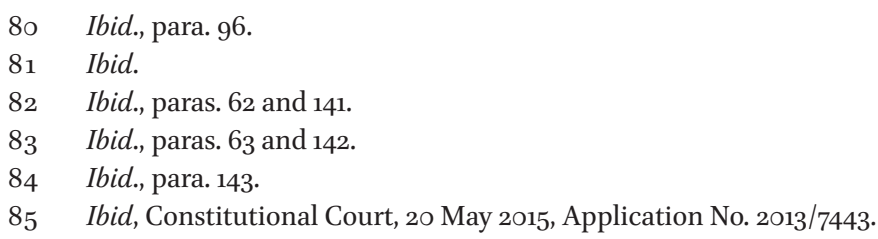


conclusive decision on this), whether the limitation pursued a legitimate aim (protection of public order), and whether the interference was necessary in a democratic society (including the test of proportionality). Ultimately, the CC decided that it was not demonstrated that the interference met a pressing social need and neither that aims pursued to protect public were proportional. ${ }^{86}$ Since the interference was not compatible with the needs of a democratic society, Article 24 of the Constitution was violated.

\section{$4 \quad$ Concluding Observations}

Despite Turkey's significant human rights obligations in the area of FoRB and the high status conferred to international human rights law under Article 90 of the Turkish Constitution, the impact of international FoRB provisions on the protection of FoRB in Turkey remains less than consistent and effective. The ECtHR judgments on diverse FoRB issues are not effectively enforced and the international standards on the right to FoRB are not applied in the various administrative, judicial and legislative processes. The right to FoRB has been restricted through acts based on "established practice", decisions of public authorities based on laws and regulations not directly dealing with FoRB and court decisions that do not apply provisions on FoRB in full compliance with international law and case-law. In the case of established practice the reason for limitations is not communicated with reference to FoRB provisions, instead with general references to "ancient customs and traditions". Restrictions related to places of worship on the outset rely on city plans, public works legislation, yet when same limitations are defended at the ECtHR level protection of "public order" provides a convenient basis for limitations. The general impact of the limitations, in whatever way they have been applied, has been to confine religious minorities to the dependency of the goodwill of public authorities, pushing old and new religious minorities outside of the law into tolerated spaces, depriving them of legal status, and maintaining state religious doctrine in the educations system. Hierarchisation may be seen in relation to the decisions on conscientious objection to military service and more consistently in the denial of place-of-worship status for the Alevi cem houses as well as the in the area of compulsory Religious Culture and Ethics courses.

The CC's excellent application of the limitation clause on the headscarf cases constitutes a stark contrast to the other cases where limitations are applied arbitrarily. The changed position of the Government on the headscarf 
may be seen as a factor. This example also demonstrates that it is not that the national authorities lack knowledge or skill to apply the limitation clause, but perhaps, "permission" to apply them.

The Turkish case also shows that international compliance control mechanisms need to exercise strict scrutiny when assessing limitations since domestic courts may, as in the case of Turkey, not apply limitation clauses in compliance with international law. Accordingly, the wide margin of appreciation given to states will not contribute to upholding the right to FoRB domestically in accordance with international human rights law. 